\title{
Treatment of intrathecal methotrexate overdose with folinic acid rescue and lumbar cerebrospinal fluid exchange: A report of two cases
}

\author{
Yüksek doz intratekal metotreksat'ın folinik asit ve beyin omurilik \\ sıvısı değişimi ile tedavisi: İki olgu sunumu
}

\author{
Elif Kazancl ${ }^{1}$, Hüseyin Gülen², Ayşe Erbay³, Canan Vergin ${ }^{4}$ \\ ${ }^{1}$ Clinics of Pediatric Hematology - Oncology, Dr. Behçet Uz Children's Hospital, Izmir, Turkey \\ 2 Department of Pediatric Hematology, Faculty of Pediatric, Celal Bayar University, Manisa, Turkey \\ ${ }^{3}$ Clinics of Pediatric Hematology - Oncology, Dr. Behçet Uz Children's Hospital, İzmir, Turkey \\ ${ }^{4}$ Clinics of Pediatric Hematology - Oncology, Dr. Behçet Uz Children's Hospital, İzmir, Turkey
}

\begin{abstract}
We report two male cases (4- and 5-years-old) of intrathecal methotrexate overdose. The two boys with acute lymphoblastic leukemia were to receive intrathecal injection of methotrexate. Instead of the prescribed $12 \mathrm{mg}$, they both received a dose of $120 \mathrm{mg}$. The initial cerebrospinal fluid samples showed methotrexate concentration of $2.24 \times 10^{-2} \mathrm{M}$ in case 1 and $1.32 \times 10^{-2} \mathrm{M}$ in case 2 . The cases were successfully treated with cerebrospinal fluid (CSF) exchange and intravenous folinic acid rescue. The favorable outcome in our cases suggests that CSF exchange is safe and that folinic acid rescue may be adequate to prevent sequelae in patients subjected to intrathecal MTX overdoses up to $120 \mathrm{mg}$. We propose CSF exchange and intravenous folinic acid as the mainstay of treatment. In addition to the staff's failure to check the drug label carefully, the marked resemblance of the two dose preparations of MTX may have been contributory. (Turk J Hematol 2011; 28: 63-7)
\end{abstract}

Key words: Methotrexate, intrathecal, overdose, treatment

Received: December 31, 2009

Accepted: June 22, 2010

\section{Özet}

Intratekal (IT) metotreksat uygulaması, merkezi sinir sistemi lösemisinin önlenmesi ve tedavisinde yaygın olarak kullanılmaktadır. Metotreksatın yüksek dozda veya uzun süreli uygulamaları ciddi nörotoksisiteye yol açabilir. Burada, hatalı olarak yüksek dozda intratekal metotreksat verilen iki olgu sunulmaktadır. Akut lenfoblastik lösemi tanısıyla izlenen 4 ve 5 yaşlarındaki iki erkek olguya, reçete edilen $12 \mathrm{mg}$ yerine yanlışlıkla $120 \mathrm{mg}$ dozunda intratekal metotreksat uyguland. Uygulama sonrası başlangıç beyin omurilik sıvısı metotreksat düzeyleri sırasıyla $2.24 \times 10^{-2} \mathrm{M}$ ve $1.32 \times 10^{-2} \mathrm{M}$ idi. Olgular beyin omurilik sıvısı değişimi ve intravenöz folinik asit desteği ile başarılı bir şekilde tedavi edildiler. 
Takiplerinde klinik gidisin iyi olması, 120 mg'a kadar yüksek doz intratekal metotreksat uygulanmış hastalarda, beyin omurilik sıvısı değişimi ve folinik asit kurtarma tedavisinin sekelleri önleme açısından yeterli olabileceğini göstermektedir. Bu hatalı uygulamaya asistanların ilaç dozlarını kontrol etmedeki hatalarının ve farklı dozlardaki metotreksat preparatlarının benzer kutularda üretilmesinin yol açtığı düşünülmüstür. (Turk J Hematol 2011; 28: 63-7)

Anahtar kelimeler: Metotreksat, intratekal, yüksek doz, tedavi

\section{Introduction}

Intrathecal (IT) methotrexate (MTX) therapy is used widely for the prevention and treatment of central nervous system (CNS) leukemia [1,2]. IT injection of MTX is becoming more popular, and may be the only form of CNS-directed therapy in selected patients [2]. Exposure to MTX in high concentrations or for sustained periods is clearly neurotoxic, and various dosage recommendations have been suggested to avoid neurotoxicity [3,4]. Clinical studies indicate that adults should receive a maximal IT dose of $12.5 \mathrm{mg}$ of MTX to avoid acute clinical neurotoxicity. Rescue treatments of IT MTX overdose may include cerebrospinal fluid (CSF) exchange, ventricular washout, folinic acid rescue, and the investigational agent carboxypeptidase G2, an enzyme that rapidly hydrolyzes MTX into inactive metabolites [5-9]. There are only a few reports of patients with IT MTX overdose in the literature, and the management has not been uniform. In this paper, we report two cases of IT MTX overdose. Similar reports from the literature and their management are reviewed.

\section{Case Reports}

\section{Case 1}

A four-year-old boy, diagnosed with pre-B cell acute lymphoblastic leukemia (ALL) without CNS involvement, started treatment according to the TRALL-BFM 2000 protocol for standard-risk ALL. The incident occurred when he received the fourth course of a 36-hour (h) continuous infusion of highdose MTX (HD-MTX, $1 \mathrm{~g} / \mathrm{m}^{2}$ ). One hour later, a dose of $120 \mathrm{mg}$ MTX instead of the prescribed $12 \mathrm{mg}$ was administered IT. Fifteen minutes later, the patient complained of intense pain in his legs. Sixty minutes after the IT MTX, the patient developed headache and generalized hypertonia, and then IT MTX overdose was suspected. The other physical find- ings of the patient were normal except for anxiety and generalized hypertonia. Systemic MTX infusion was stopped immediately and exchange of lumbar CSF was started 90 minutes (min) after the IT MTX. He was returned to the operating theater and a repeat lumbar puncture was performed under general anesthesia. Twenty milliliters of dark yellow CSF was removed by gravity over a period of $20 \mathrm{~min}$. No complication was observed during the procedure. CSF MTX concentrations were measured by means of an enzyme-inhibition technique [10]. The initial CSF sample had MTX concentration of $2.24 \mathrm{x}$ $10^{-2}$ M. $20 \mathrm{ml}$ saline was administered IT instead of CSF $1.5 \mathrm{~h}$ after the IT HD-MTX. Twenty milliliters of normal saline was then introduced, started approximately $1.5 \mathrm{~h}$ after the IT dose. Subsequently, $210 \mathrm{ml}$ of CSF were removed in 5-ml portions and replaced by a corresponding volume of pre-warmed normal saline. Thus, a total volume of $230 \mathrm{ml}$ was exchanged, equivalent to $200 \mathrm{ml} / \mathrm{m}^{2}$, over a period of $2 \mathrm{~h}$ and 15 min [7]. Two hours after the IT MTX, folinic acid was started intravenously (IV) at a dose of $100 \mathrm{mg}$ single, and then doses of $10 \mathrm{mg}$ every $6 \mathrm{~h}$ for $24 \mathrm{~h}$ $[5,13,15,16]$. Dexamethasone was also used at a dose of $0.15 \mathrm{mg} / \mathrm{kg}$ IV every $6 \mathrm{~h}$ for 2 days. CSF examination, liver and kidney functions and electrolytes were found in normal limits. At 1 and 6 months, electroencephalogram (EEG) and a brain computed tomography (CT) scan were normal. The patient remained in normal neurological status thereafter. No signs of neurotoxicity were observed during the following four years.

\section{Case 2}

The second patient was a five-year-old boy with $\mathrm{T}$ cell ALL, without CNS involvement, in whom treatment was started according to the TRALL-BFM 2000 protocol for medium-risk ALL. During the maintenance phase (Protocol II $45^{\text {th }}$ day therapy), an IT dose of $120 \mathrm{mg}$ of MTX instead of the intended $12 \mathrm{mg}$ was accidentally given by the pediatrics staff. 
A vial with a 10-fold higher concentration of MTX had erroneously been used for the preparation of the injection solution. Ninety minutes after the IT, the patient developed headache. The mistake was discovered $2 \mathrm{~h}$ later, and then $200 \mathrm{ml}$ of CSF were exchanged with normal saline in 5-ml portions over a 3 -h period via lumbar puncture. The initial CSF sample had a MTX concentration of $1.32 \times 10^{-2} \mathrm{M}$. Two hours after the IT MTX, folinic acid was started IV at a dose of $100 \mathrm{mg}$ single, and then doses of 10 mg every $6 \mathrm{~h}$ for $24 \mathrm{~h}$. Dexamethasone was also used at a dose of $0.15 \mathrm{mg} / \mathrm{kg}$ IV every $6 \mathrm{~h}$ for 2 days. No neurological signs were observed before or after the CSF exchange procedure. The child remained asymptomatic in complete remission, and EEG and CT of the brain performed six months after the incident were normal. Written informed consent was obtained from both of the patients' family.

\section{Discussion}

Methotrexate (MTX) has been used extensively in the treatment of various malignancies, including lymphoblastic leukemia and lymphoma. HD-MTX with leucovorin rescue is used to treat osteosarcoma $\left(8-12 \mathrm{~g} / \mathrm{m}^{2}\right)$ and ALL $\left(\leq 8 \mathrm{~g} / \mathrm{m}^{2}\right)$. The toxic effects of MTX are myelosuppression, mucositis, nephrotoxicity, hepatotoxicity, and neurotoxicity with acute or chronic encephalopathy [11-17]. Acute encephalopathy generally develops within 5-14 days after IT MTX or HD-MTX and may include headache, nausea, emesis, lethargy, altered mental status, blurred vision, aphasia, hemiparesis, and seizure. Chronic encephalopathy develops slowly, may progress, and can permanently impair neurologic function. Transient acute encephalopathy has been clinically observed in 3\%-15\% of cancer patients after HD- MTX [12,15,16]. Most patients can resume MTX therapy without permanent neurological sequelae, although $10 \%$ - 56\% may experience recurrence on rechallenge $[12,15,16]$. The pathophysiology of MTX-induced acute encephalopathy is largely unknown but does not appear to be related to MTX pharmacokinetics [12]. The usual dose for IT administration is $12-15 \mathrm{mg}$. Management of IT MTX overdose is not uniform and, in fact, cases described in the literature have been treated with different approaches [18-24]. The highest reported IT dose given to patients who survived was $650 \mathrm{mg}$
[5]. The neurotoxicity of MTX is both route- and dose-dependent. There is little neurotoxicity when MTX is given orally or intravenously, as the drug does not reach significant concentration in the CSF. However, IV HD MTX has been associated with CNS toxicity, and systemic toxicity may be seen following IT administration. Common findings included behavioral abnormalities, focal sensorial and motor signs and abnormal reflexes [15]. Manifestations of IT MTX overdoses are dose-dependent. It is associated with little or mild toxicity at less than $100 \mathrm{mg}$. However, doses in excess of $100 \mathrm{mg}$, and particularly in excess of $500 \mathrm{mg}$, may cause significant morbidity and mortality [5,19].

To our knowledge, 13 cases of IT MTX overdose have been reported in the literature (Table 1). Twelve of the 13 reported incidents involved children between the ages of 2-12 years. Eight patients suffered from ALL and the other four had non-Hodgkin's lymphoma. Nine cases received 20-125 mg of IT MTX. In one of them, folinic acid rescue was administered IT and resulted in a fatal event. Nine cases were treated with folinic acid, dexamethasone and CSF exchange. No neurologic long-term sequelae were observed in any of these nine patients [20-24]. Three cases received $600-650 \mathrm{mg}$ of IT MTX and underwent ventriculolumbar perfusion or CSF exchange, which are considered effective if performed promptly $[5,6,18]$. In ventriculolumbar perfusion, CSF is exchanged for warmed, isotonic saline solution $[6,18]$.

From these reports, it is obvious that severe toxicity is expected when an IT MTX overdose of more than $600 \mathrm{mg}$ occurs. Carboxypeptidase G1 and G2 are investigational agents that rapidly hydrolyze MTX into inactive metabolites [9]. It has been successfully used IT for treatment of IT MTX overdose [18]. However, these agents are not commercially available at present.

Incorrect prescription and failure to check the drug label carefully prior to the injection are apparently the most immediate errors [25]. In our reported cases, the marked resemblance of the two strengths of parenteral MTX preparations (i.e. 50 $\mathrm{mg} / 5 \mathrm{ml}$ and $500 \mathrm{mg} / 5 \mathrm{ml}$, respectively) may also have been contributory.

In conclusion, our patients were treated successfully with IV high doses of folinic acid and lumbar CSF exchange. Cases receiving overdoses of IT MTX should first be treated with CSF exchange and IV 
Table 1. Reported cases of intrathecal methotrexate overdose

\begin{tabular}{|c|c|c|c|c|}
\hline Reference & $\begin{array}{c}\text { Age } \\
\text { (year) }\end{array}$ & $\begin{array}{c}\text { IT MTX } \\
\text { dose (mg) }\end{array}$ & Rescue treatment & Folinic acid dose \\
\hline \multirow[t]{2}{*}{ Ettinger $(5) *$} & 9 & 650 & CSF exchange & $50 \mathrm{mg} x 2+12 \mathrm{mg} \mathrm{q} 6 \mathrm{~h} \times 2 \mathrm{wk}$ \\
\hline & & & IV folinic acid + dexamethasone & \\
\hline \multirow[t]{2}{*}{ Spiegel et al. (6) } & 26 & 625 & Ventriculolumbar perfusion & $200 \mathrm{mg} / \mathrm{m}^{2} \mathrm{q} 3 \mathrm{~h} \times 8+150 \mathrm{mg} \mathrm{q} 3 \mathrm{~h}$ x 32 \\
\hline & & & IV folinic acid + thymidine & \\
\hline O’Marcaigh et al. (18) & 6 & 600 & $\begin{array}{l}\text { Ventriculolumbar perfusion } \\
\text { IV folinic acid + dexamethasone } \\
\text { Carboxypeptidase-G2 IT }\end{array}$ & $1000 \mathrm{mg} / \mathrm{m}^{2}+100 \mathrm{mg} / \mathrm{m}^{2} \mathrm{q} 3 \mathrm{~h} \times 12$ \\
\hline Riva et al. (23) & 7 & 300 & IV folinic acid + dexamethasone & $120 \mathrm{mg} / \mathrm{m}^{2}$ levo product $\mathrm{q} 3 \mathrm{~h} \times 8+\mathrm{q} 6 \mathrm{~h} \times 4$ \\
\hline Lee et al. (24) & 3 & 125 & IV folinic acid + dexamethasone & 15 mg q3 h x8 + 30 mg q6 h x12 \\
\hline Lee et al. (24) & 4 & 125 & IV folinic acid + dexamethasone & 15 mg q3 h x $8+30$ mg q6 h x 12 \\
\hline Jakobson et al. (7) & 11 & 120 & $\begin{array}{l}\text { CSF exchange } \\
\text { IV folinic acid }\end{array}$ & 90 mg + 15 mg q3 h x16 \\
\hline Jakobson et al. (7) & 4 & 100 & $\begin{array}{l}\text { CSF exchange } \\
\text { IV folinic acid + dexamethasone }\end{array}$ & Not specified \\
\hline Ettinger et al. (22) & 2 & 85 & IV folinic acid + dexamethasone & $85 \mathrm{mg}+6 \mathrm{mg} \mathrm{q} 6 \mathrm{~h} \times 4$ \\
\hline Addiego et al. (20) & 12 & 50 & $\begin{array}{l}\text { CSF exchange } \\
\text { IV folinic acid + dexamethasone }\end{array}$ & Not specified \\
\hline Addiego et al. (20) & 4 & 50 & $\begin{array}{l}\text { CSF exchange } \\
\text { IV folinic acid + dexamethasone }\end{array}$ & $12 \mathrm{mg} \mathrm{q} 12 \mathrm{~h} \times 6$ \\
\hline Lampkin et al. (21) & 4 & 52 & IM folinic acid & $12 \mathrm{mg}+6 \mathrm{mg} \mathrm{q} 4 \mathrm{~h} \times 9$ \\
\hline Jardine et al. (19)* & 11 & 20 & IT folinic acid + IV folinic acid & 100 mg q4 h x24 \\
\hline
\end{tabular}

*: Fatal outcome; IT: Intrathecal; IV: Intravenous; MTX: Methotrexate

folinic acid rescue. More important, doctors and nurses who treat malignant diseases must be very careful in all stages of disease care, such as in the prescribing, ordering and administering of medicines and the following of adverse or unexpected effects.

\section{Conflict of interest statement}

None of the authors of this paper has a conflict of interest, including specific financial interests, relationships, and/or affiliations relevant to the subject matter or materials included.

\section{References}

1. Bleyer WA, Poplack DG. Prophylaxis and treatment of leukemia in the central nervous system and other sanctuaries [Review]. Semin Oncol 1985;12:131-48.

2. Poplack DG. Acute lymphoblastic leukemia. In: Pizzo PA, Poplack DG, editors. Principles and Practice of Pediatric Oncology. Philadelphia: Lippincott, 1993:431-81.
3. Bleyer WA, Drake JC, Chabner BA. Neurotoxicity and elevated cerebrospinal-fluid methotrexate concentration in meningeal leukemia. $\mathrm{N}$ Engl $\mathrm{J}$ Med 1973;289:770-3. [CrossRef]

4. Addiego JE Jr, Ridgway D, Bleyer WA. The acute management of intrathecal methotrexate overdose: pharmacologic rationale and guidelines. $\mathrm{J}$ Pediatr 1981;98:825-8. [CrossRef]

5. Ettinger LJ. Pharmacokinetics and biochemical effects of a fatal intrathecal methotrexate overdose. Cancer 1982;50:444-50. [CrossRef]

6. Spiegel RJ, Cooper PR, Blum RH, Speyer JL, McBride D, Mangiardi J. Treatment of massive intrathecal methotrexate overdose by ventriculolumbar perfusion. $\mathrm{N}$ Engl J Med 1984;311:386-8. [CrossRef]

7. Jakobson AM, Kreuger A, Mortimer O, Henningsson S, Seidel H, Moe PJ. Cerebrospinal fluid exchange after intrathecal methotrexate overdose. A report of two cases. Acta Paediatr 1992;81:359-61. [CrossRef]

8. Widemann BC, Balis FM, Murphy RF, Sorensen JM, Montello MJ, O'Brien M, Adamson PC[p3]. Carboxypeptidase-G2, thymidine and leucovorin rescue in cancer patients with methotrexate-induced renal dysfunction. J Clin Oncol 1997;15:2125-34. 
9. Adamson PC, Balis FM, McCully CL, Godwin KS, Bacher JD, Walsh TJ, Poplack DG[p4]. Rescue of experimental intrathecal methotrexate overdose with carboxypeptidase-G2. J Clin Oncol 1991;9:670-4.

10. Falk LC, Clark DR, Kalman SM, Long TF. Enzymatic assay for methotrexate in serum and cerebrospinal fluid. Clin Chem 1976;22:785-8.

11. Relling MV, Fairclough D, Ayers D, Crom WR, Rodman $\mathrm{JH}$, Pui CH, Evans WE. Patient characteristics associated with high-risk methotrexate concentrations and toxicity. J Clin Oncol 1994;12:1667-72.

12. Rubnitz JE, Relling MV, Harrison PL, Sandlund JT, Ribeiro RC, Rivera GK, Thompson SJ, Evans WE, Pui $\mathrm{CH}$. Transient encephalopathy following high-dose methotrexate treatment in childhood acute lymphoblastic leukemia. Leukemia 1998;12:1176-81. [CrossRef]

13. Mahoney DH Jr, Shuster JJ, Nitschke R, Lauer SJ, Steuber CP, Winick N, Camitta B. Acute neurotoxicity in children with B-precursor acute lymphoid leukemia: an association with intermediate-dose intravenous methotrexate and intrathecal triple therapy-a Pediatric Oncology Group study. J Clin Oncol 1998;16:1712-22.

14. Atra A, Pinkerton CR, Bouffet E, Norton A, Hobson R, Imeson JD, Gerrard M; United Kingdom Children Cancer Study Group/Non-Hodgkin Lymphoma Group. Acute neurotoxicity in children with advanced stage B-non-Hodgkin's lymphoma and B-acute lymphoblastic leukaemia treated with the United Kingdom children cancer study group 9002/9003 protocols. Eur J Cancer 2004;40:1346-50. [CrossRef]

15. Walker RW, Allen JC, Rosen G, Caparros B. Transient cerebral dysfunction secondary to high-dose methotrexate. J Clin Oncol 1986;4:1845-50.
16. Jaffe N, Takaue Y, Anzai T, Robertson R. Transient neurologic disturbances induced by high-dose methotrexate treatment. Cancer 1985;56:1356-60. [CrossRef]

17. Packer RJ, Grossman RI, Belasco JB. High dose systemic methotrexate-associated acute neurologic dysfunction. Med Pediatr Oncol 1983;11:159-61. [CrossRef]

18. O'Marcaigh AS, Johnson CM, Smithson WA, Patterson MC, Widemann BC, Adamson PC, McManus MJ. Successful treatment of intrathecal methotrexate overdose by using ventriculolumbar perfusion and intrathecal instillation of carboxypeptidase G2. Mayo Clin Proc 1996;71:161-5. [CrossRef]

19. Jardine LF, Ingram LC, Bleyer WA. Intrathecal leucovorin after intrathecal methotrexate overdose. J Pediatr Hematol Oncol 1996;18:302-4. [CrossRef]

20. Addiego E, Ridgway D, Bleyer WA. The acute management of intrathecal methotrexate overdose: pharmacologic rationale and guidelines. J Pediatr 1981;98:825-8. [CrossRef]

21. Lampkin BC, Higgins GR, Hammond D. Absence of neurotoxicity following massive intrathecal administration of methotrexate: case report. Cancer 1967;20:1780-1. [CrossRef]

22. Ettinger LJ, Freeman AI, Creaven PJ. Intrathecal methotrexate overdose without neurotoxicity: case report and literature review. Cancer 1978;41:1270-3. [CrossRef]

23. Riva L, Conter V, Rizzari C, Jankovic M, Sala A, Milani M. Successful treatment of intrathecal methotrexate overdose with folinic acid rescue: a case report. Acta Paediatr 1999;88:780-2. [CrossRef]

24. Lee ACW, Wong KW, Fong KW. Intrathecal methotrexate overdose. Acta Paediatr 1997;86:434-7. [CrossRef]

25. Poplack DG. Massive intrathecal overdose: "Check the label twice!" N Engl J Med 1984;31:400-2. [CrossRef] 